\title{
Forest School as a Way of Learning in the Outdoors in the UK
}

\author{
Sara Knight \\ Anglia Ruskin University, UK
}

\begin{abstract}
My research paper focuses on the first phase of a project to examine Forest School as a way of facilitating experiential learning in the outdoors in the United Kingdom. The first phase starts with a consideration of the defining characteristics of Forest School by analyzing fourteen case studies of Forest School experience, used with different agegroups in different settings across the UK. The study uses a grounded theory approach and utilizes the computer software package NVivo 8 as a coding tool. It then uses the initial codes and comparisons to facilitate discussion with the other lead practitioners in Forest School in the UK, to debate whether these are the necessary and sufficient conditions for Forest School, and to reach a coconstructed consensus national perspective. In a later phase of my research $I$ will be exploring the transferability of these characteristics to Forest School in the early years community, typically with practitioners working with two to five year old, as this is the age group that I typically work with..
\end{abstract}

\section{Introduction}

My research focuses upon the phenomena of Forest School as a way of facilitating experiential learning experiences outdoors. My own work has been with two to five year old children in England but as can be seen [7] this is only one way of using this innovative intervention technique. It is, however, the first way in which Forest School was developed in the UK, as can be seen in the next paragraph. Forest School is also now used in all areas of the UK, having spread rapidly from the South West of England.

Forest School in the UK was based on Danish early years outdoor pedagogy (Skogsbarnehargen) related to Friluftsliv [2] and was developed following a trip to Denmark in 1993 by staff and students from the Early Years Education Department at Bridgwater College in Somerset. Initially they imitated the Danish model they had seen [23], and used it as a way of working with the children in their college day nursery, but then adapted the idea for use with older students with special needs. Beneficial outcomes recorded for these students included improvements in self-esteem, motivation and concentration.
As the wider scope of its value became apparent, it was adopted as an entitlement for every student in the college as a part or their Personal, Social and Emotional (PSE) development [9]. In subsequent years the intervention (i.e. spending time being close to nature) has spread and is now used across the UK and across client groups [7], although programmes with three to five year olds are still the most common. Training organizations have developed, to educate and qualify practitioners from a range of backgrounds to deliver Forest School, and a national group has formed, called the Institute for Outdoor Learning Forest School Special Interest Group (IOL FSSIG). I sit on that committee, and our aim is eventually to create a National Governing Body to accredit professional standards for delivery and to regulate training standards, working with the National Forest School Training Network, an overlapping and allied group whose sole function is to agree on how Forest School leaders should be trained.

My interest is as a lead practitioner, writer and academic in this field, and the focus of my research reflects my concerns that the defining characteristics which make Forest School a distinctive program, and the likely outcomes that might be expected from such programmes, have not been agreed nationally. It is clear from reading recent papers $[15 ; 18 ; 11 ; 22$; 21] that what some are accepting (and some are rejecting) as Forest School experiences are very different. It is true that strongly-held beliefs have evolved differently across the UK, with all concerned being passionately committed to what they "know" to be true, but that truth has developed in slightly different ways under local conditions and influences.

The Forest School idea has had over ten years to get started, and is on the cusp of becoming a respected and established intervention in schools for all ages of children and young people, as well as moving out into the community as a way of working with vulnerable groups. If we cannot reach a consensus about what Forest School is now, there is a fear that there may be splits between the different perspectives that will waste energies and cause unnecessary rivalries. In addition, it is becoming necessary to "place" Forest School within the discipline of outdoor learning, and to do that means to establish agreed parameters.

Given the above conditions, I am starting my research by considering and attempting to identify 
the defining characteristics of Forest School. Over the last eighteen months I have been working on an edited book [7] which contains accounts by sixteen Forest School practitioners of their Forest School sessions, and (with their permission) I have undertaken a thematic review of these case studies. These Forest School sessions have been with the full spectrum of ages and abilities, thus exploring the scope of how Forest School has been identified as a useful concept, and how it has been implemented in practice. I am using the computer software package NVivo 8 to code and categories the case studies, looking for recurring themes and patterns that will indicate what the underpinning values of the different practitioners are, and what the commonalities are. In this way I have developed a definition from the ground up of what Forest School might be.

My next step will be to discuss my findings with the other lead practitioners in the Forest School Trainers Network. Some of the authors of the case studies that I have been unpicking for underpinning values are also members of this network, being themselves involved in the training of others, but many members have not been involved in the writing of the book, and are unaware of my research. All members of the Network are people involved in training others to lead Forest School sessions, and so I would hope that they have already reflected on what is unique about the ethos that they are transmitting. I wish to have a debate with them about whether my findings represent the defining features of Forest School, making the implicit explicit. If not, I wish to find out what they believe is missing from the jigsaw. My intention is that we will co-construct reach a consensus national perspective.

Next, I will be researching the transferability of these characteristics to Forest School with the wider early years community, typically with practitioners working with two to five year olds. In this way I will be retracing the origins of Forest School in a cyclical manner. Finally I will close the loop by considering the international development of Forest School-type provision in the early years, and how my definition matches experiences in other countries.

\section{A Review of the Extant Literature about UK Forest School}

The characteristics of Forest School were first listed by staff at Bridgewater College, but their early printed materials are no longer available. However, the Forestry Commission, who have supported Forest School from its earliest days, commissioned the new Economics Foundation (NEF) to develop an evaluation scheme for Forest School with three to five year olds, starting in the early years of this century. This resulted in a number of papers by Liz
O'Brian, a research officer with the Forestry Commission, and Richard Murray of NEF $[14 ; 13$; $17 ; 16 ; 15]$. These papers list eight propositions which were identified by the project team and which were measured as outcomes by the early years teachers involved in the early projects involved. The system thus developed by NEF in Wales was replicated in Scotland [3] and by me in Suffolk [9] in 2006 , but I felt that by starting with pre-determined outcomes based on the priorities identified in early years settings that there was a risk that they could become a restrictive lens for seeing Forest School. In addition, Tricia Maynard [11] undertook interviews with three Forest School and early years practitioners, and noted differences between the outcomes and ethos as identified by the NEF studies and those she found in settings not affiliated to the Forestry Commission. As the Forest School movement embraces more diversity, so it calls for a more open approach to analysis

In England the Early Years Foundation Stage Curriculum for children up to the age of five years culminates in an assessment called the Foundation Stage Profile. I piloted an attempt to use this to recording outcomes [8], but felt that this, too, missed capturing the distinctive quality of the Forest School experience. However, subsequent to this, some local education authorities have pursued this methodology, as it gives outcomes that meet government targets, and is thus popular with politicians. This raises a further issue that of finding a measure that will enable data to be collected that is useable as evidence to support funding and future developments. However, my concern remains that the effectiveness of an intervention cannot be efficiently and accurately measured until it is possible to state clearly what that intervention is.

Tim Waller [22] describes an experience with three to five year olds that resonates with me as Forest School, but he has elected not to label it as such because it does not resemble the Forest School sessions he has seen. There is clearly a difference in practice here which emphasizes that different definitions of Forest School and its core ethos have evolved, and so it would seem timely to work towards clarifying what constitutes Forest School in the UK context.

\section{Research Rationale}

My desire is to open up discussion, and to coconstruct a consensus view of what Forest School is with other lead practitioners in a democratic manner. This has led me to adopt an ethnographic, constructivist approach [19]. I believe this to be possible as I can claim to be a part of the Forest School world, as a trained Forest School leader and a member of the IOL FSSIG, making this approach a possibility. The problem of defining Forest School 
is real to me and to my colleagues, and we recognize that now is the right time to seek out this particular "truth" [5].

I am analyzing my data using a grounded theory method [4], and the NVivo 8 statistical package to support this. Following the initial coding of the data I will take my findings to the IOL FSSIG for reflection and comment. I will then return to the data and revisit the theoretical categories before taking the findings to semi-structure interviews with the National Forest School Training Network, with a view to developing an agreed hierarchy of characteristics. After further refinement, I will use them to compare different early years Forest School sessions using observations, and interviews with participants (children) and practitioners. At this point I will be seeking ethical approval for my work with children.

\section{Contributions to Knowledge}

\subsection{Contributing practitioners}

My collected sixteen case studies are all from practitioners qualified to run Forest School sessions by completing a Forest School Leadership award validated by either the Open College Network or BTEC (now EdExel), the two exam boards recognized by the FSSIG. These courses are at a level (Vocational Qualification level 3), recognized in the UK as enabling adults to be given supervisory responsibility for children, and cover a range of theoretical knowledge and practical skills. They have been developed over a number of years by practitioners who consult with each other to maintain standards through the National Forest School Training Network. The intention is to give those coming to Forest School from education, in other words teachers or early years professionals, a level playing field with those who come to Forest School from Forestry or Outdoor Activities. Practitioners thus learn about child development, to increase the understanding of the pedagogy in the Foresters, alongside Bushcraft skills to increase the understanding of safety and skills in the woods in educationalists.

Here the similarity ends, as does any limitation on my sampling. Contributors came from a wide range of backgrounds, and were self-selecting. I put out a request through the IOL FSSIG, the Forestry Commission and through personal contacts for contributors who, at this stage, were only aware that they would be contributing to a book. It was only after I had collected their stories and realized what an interesting accumulation of data had presented itself, that I returned to my authors and asked them if they would mind if I used the data for research. For ethical reasons I will keep them informed at all stages so that they can withdraw their permission.
Chart 1 below looks at the attributes I have assigned to each case study to capture the range of leader qualifications and experience, and the contexts in which they provide Forest School. It was easy to identify which authors came from education backgrounds, in other words they were teachers, lecturers and early years practitioners. The other group came from an outdoor education perspective, often also trained in forestry or outdoor pursuits. However, a closer examination of all sixteen revealed that ten of them have additional ways in which they identify themselves. Two are artists, three are therapists, three are Forest School Trainers (they train others to become Forest School practitioners), and two have strategic responsibilities in their job role. These additional interests may, I believe, color their perspectives about their Forest School sessions, both in terms of what sessions they offer, and what the features are that they believe to be most important. I do not see as a negative feature, but more in the light of the positive richness they have brought to the developing concept of Forest School. In figure 4 below, I show the overlapping influences on Forest School that come from this rich input, and below I reflect briefly on the impact that this might have on establishing a definition of Forest School

The columns do not read left to right, they are independent of each other.

Table 1. Leadership Attributes

\begin{tabular}{|c|c|}
\hline Main author category & $\begin{array}{c}\text { Secondary author } \\
\text { category }\end{array}$ \\
\hline Educator (7) & Artist or creator (2) \\
\hline Outdoor educator (9) & $\begin{array}{c}\text { Therapist or counselor } \\
(3)\end{array}$ \\
\hline & $\begin{array}{c}\text { Forest School trainer } \\
(3)\end{array}$ \\
\hline & $\begin{array}{c}\text { Strategist (2) } \\
\text { No additional } \\
\end{array}$ \\
\hline
\end{tabular}

As stated above, the variety of specialists represented here reflects the different emphasis placed on the different elements and the prioritization that they are given. The homogeneity lies in their initial Forest School training, emphasizing how important it is to achieve a consensus definition with the Forest School Training Network. 


\subsection{Contributing settings}

The groups were located across the whole of the UK, with the exception of Northern Ireland. I did initially have a contributor from there but he had to drop out when a local reorganization affected his job role. I am aware, however, that Forest School is flourishing in Northern Ireland, and look forward to including developments there at a later stage of my research.

Interestingly, half of the case studies were with urban client groups (the residential setting is rural). This contrasts with earlier studies where the majority of settings were rural. There is not, however, a correlation between socio-economic and geography.

I was fortunate in receiving contributions from settings that were in the main dissimilar from the focus of earlier studies, which were all with children between the ages of three and six years. This enabled me to hope that by working with a wider range of groups I could engage in a correspondingly wider exploration of the possibilities of Forest School at this early stage. I do have one early years group, but they are urban (other studies have been rural), plus two primary groups, and five groups concerned with clients of secondary school age, although some of them are not attending school. My residential group crosses the primary and secondary ages, as does one of the two that focus on clients with special educational needs. Life-long learning looks at the wider picture for all ages, with one cohort of adults. The community group is one where parents and their children of all ages come together.

Table 2. Attributes of groups discussed

\begin{tabular}{|c|c|c|}
\hline Level/age of participants & $\begin{array}{l}\text { Possible } \\
\text { effects of } \\
\text { socio- } \\
\text { economic } \\
\text { deprivation }\end{array}$ & Location \\
\hline $\begin{array}{c}\text { Early years under five } \\
\text { years old (1) }\end{array}$ & \multirow{2}{*}{$\begin{array}{l}3 \text { studies focus } \\
\text { on areas of } \\
\text { deprivation }\end{array}$} & Urban (8) \\
\hline $\begin{array}{c}\text { Primary, between } 5 \text { and } \\
11 \text { years old (2) }\end{array}$ & & Rural (7) \\
\hline $\begin{array}{l}\text { Secondary, between } 11 \\
\text { and } 16 \text { years old(5) }\end{array}$ & \multirow{4}{*}{$\begin{array}{c}\text { A further } 6 \\
\text { target clients } \\
\text { identified as } \\
\text { possibly } \\
\text { suffering from } \\
\text { the effects of } \\
\text { deprivation }\end{array}$} & Residential (1) \\
\hline $\begin{array}{l}\text { Children's home, children } \\
\text { are under } 16 \text { years old } \\
(1)\end{array}$ & & \\
\hline $\begin{array}{l}\text { Lifelong learning, for } \\
\text { groups over } 16 \text { years old } \\
(4)\end{array}$ & & \\
\hline $\begin{array}{l}\text { Community groups, for } \\
\text { families (1) }\end{array}$ & & \\
\hline $\begin{array}{c}\text { Children with Special } \\
\text { Educational Needs, all } \\
\text { ages (2) }\end{array}$ & $\begin{array}{c}7 \text { are } \\
\text { unconnected }\end{array}$ & \\
\hline
\end{tabular}

\subsection{First Conceptual Categories}

The categories identified in the previous research which is cited in the literature review above, and which focused on the Early Years, have been conceptualized in relation to outcomes, in other words what Forest School does, rather than identifying what Forest School is. As indicated in 1.2 above, this puts the definitions round the wrong way, because outcomes cannot be accurately determined until the entity itself has been identified. Without this, it is possible that variables will cloud the results and give false impressions of what can and cannot be achieved through a Forest School intervention.

Previous research has been linked to the English Early Years Foundation Stage Curriculum [8] or to the concerns of Early Years Practitioners [14]. By widening the scope of the discussion to a range of other groups, different defining features are being identified. It is possible that at a later stage I will find that some of those earlier categories will be identifiable as subsets of the final versions of the categories above, but at this stage I am trying to "forget" them, lest they influence my reading of the case studies.

Table 1 above, of Leadership Attributes, shows the range of leader qualifications, and Table 2 shows the contexts in which they provide Forest School. The next stage is to examine the case studies and code the conceptual categories that appear there.

In line with a grounded theory approach I am revisiting my data repeatedly. I am still in the initial coding phase with the case studies. My first and second readings have revealed the conceptual categories shown in Table 3 Conceptual categories from case studies, below. I have sorted them into alphabetical order to remove any sense of prioritization at this stage.

\section{Chart 3. Conceptual categories from case studies}

\begin{tabular}{|c|c|}
\hline Conceptual category & Key words used \\
\hline \multicolumn{2}{|l|}{$\begin{array}{l}\text { Brain processes neural } \\
\text { pathways }\end{array}$} \\
\hline \multicolumn{2}{|l|}{$\begin{array}{l}\text { Calming, } \\
\text { distressing }\end{array}$} \\
\hline $\begin{array}{l}\text { Establishing a base } \\
\text { camp }\end{array}$ & $\begin{array}{l}\text { Belonging } \\
\text { ownership }\end{array}$ \\
\hline $\begin{array}{l}\text { Freedom to be in unsafe } \\
\text { places }\end{array}$ & $\begin{array}{l}\text { Personal responsibility, } \\
\text { independence }\end{array}$ \\
\hline Healthy habits & Exercise, food \\
\hline $\begin{array}{ll}\text { Holistic } & \text { learning } \\
\text { opportunities } & \\
\end{array}$ & $\begin{array}{l}\text { Natural curiosity, } \\
\text { learning attainment }\end{array}$ \\
\hline \multicolumn{2}{|l|}{ Importance of fire } \\
\hline $\begin{array}{l}\text { Importance of wild } \\
\text { natural spaces }\end{array}$ & Nurturative nature \\
\hline Leader-led relationship & $\begin{array}{l}\text { Trust, attachment, } \\
\text { interdependency, Role } \\
\text { model }\end{array}$ \\
\hline
\end{tabular}




\begin{tabular}{|l|l|}
\hline $\begin{array}{l}\text { learner initiated/learner } \\
\text { led }\end{array}$ & $\begin{array}{l}\text { Rights, responsibilities, } \\
\text { decision-making, } \\
\text { negotiated, open ended }\end{array}$ \\
\hline $\begin{array}{l}\text { Magic, mystery, } \\
\text { spirituality of nature }\end{array}$ & $\begin{array}{l}\text { Awe and wonder, } \\
\text { imagination, fantasy, } \\
\text { creativity }\end{array}$ \\
\hline $\begin{array}{l}\text { Natural activities with } \\
\text { real purpose }\end{array}$ & Dens, bushcraft skills \\
\hline $\begin{array}{l}\text { Parental partnerships } \\
\text { community links }\end{array}$ & $\begin{array}{l}\text { Inclusion, participation, } \\
\text { societal links }\end{array}$ \\
\hline $\begin{array}{l}\text { Preventing/remediating } \\
\text { social exclusion }\end{array}$ & $\begin{array}{l}\text { Group on } \\
\text { interdependency }\end{array}$ \\
\hline $\begin{array}{l}\text { Respect/love } \\
\text { environment }\end{array}$ & $\begin{array}{l}\text { Awareness of weather, } \\
\text { seasons, } \\
\text { connectedness, valuing }\end{array}$ \\
\hline Trained leaders & $\begin{array}{l}\text { CPD plus skills, } \\
\text { empathy, share }\end{array}$ \\
\hline $\begin{array}{l}\text { Over time, repeated } \\
\text { occurrences }\end{array}$ & $\begin{array}{l}\text { All expressed negatively, } \\
\text { as in not rushed, not } \\
\text { interrupted, not tidied } \\
\text { away }\end{array}$ \\
\hline
\end{tabular}

My research is at a very early stage but, in the spirit of "systematic conceptualization and constant comparisons" [20] now is an ideal moment for me to seek contributions and comments from colleagues. This will happen shortly, when I meet with the IOL FSSIG committee. After taking on board their comments I will be meeting with the National Forest School Training Network, which will mark a significant point in my research.

\section{Overlapping Conceptual Frameworks}

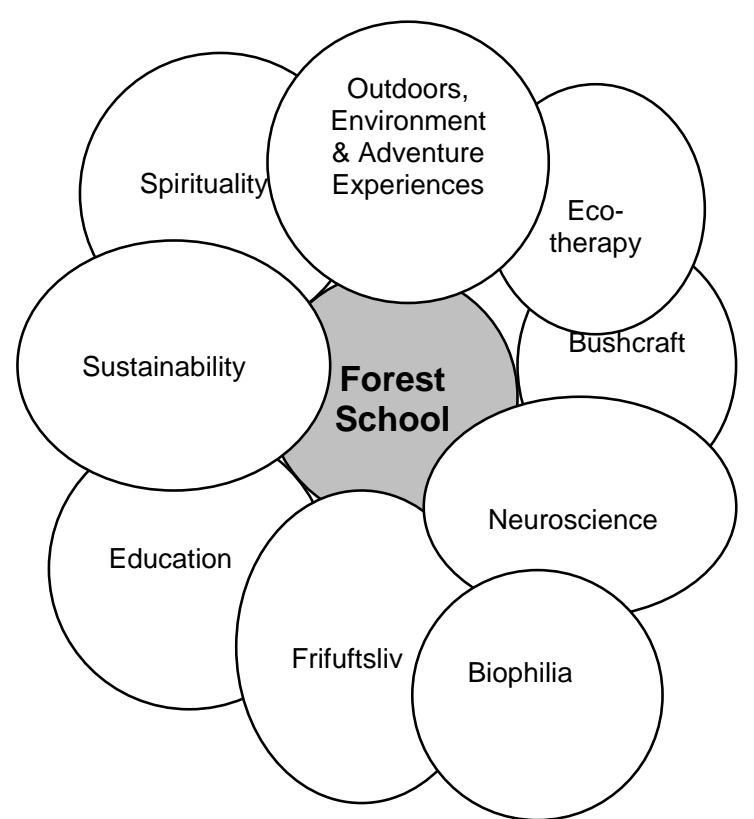

Figure 1. Some of the overlaps [7]

The figure above is an adaptation of one which I created for the conclusion of my latest book [7], where I consider how different conceptual frameworks overlap and influence Forest School. The research I have described thus far in this paper is a bottom-up grounded theory approach to defining Forest School. Once I have progressed as far as I can with that approach, at some point I will need to address the issues illustrated by the overlaps shown above.

I hope that from my research I will be able to identify which of the bottom-up categories form a unique core which identify what Forest School is, and which belong to the overlapping "others" that influence how a particular Forest School iteration reflects the strengths of the leading practitioner and the needs of their client group. In this way, the singularity of Forest School should be robust enough to encompass the variety of ways in which Forest School can be legitimately expressed.

\section{Conclusions}

The process of defining Forest School is particularly pertinent to an international audience, as the resurgence of the importance of contact with nature is not unique to the UK in anyway. Richard Louv's influential book [10] has spurred many into espousing and celebrating (re)connection with the natural world as important both to our species and to the planet. The initial results are encouraging me to think that I can establish what the unique ethos is that defines Forest School, and what the necessary and sufficient conditions are for its delivery that will enable a variety of projects to thrive under the Forest School banner.

The research will be made available to FSSIG colleagues as we set up a National Governing Body for Forest School in the UK, and internationally as Forest School becomes popular in other countries including Canada, the US, Australia and other European states. I will value the contribution of international colleagues to this enquiry.

\section{References}

[1] Bell, J., "Doing Your Research Project ( $4^{\text {th }}$ Edt)", Open University Press: Maidenhead, UK, 2005

[2] Bentsen, P., Mygind, E. \& Randrup, T. B., "Towards an understanding of udeskole: education outside the classroom in a Danish context", Education 3-13, Routledge: London, UK, 2009, 37:1,29 — 44

[3] Borradaille, L., "Forest School Scotland: An Evaluation", Forestry Commission Scotland, www.forestry.gov.uk, 2006

[4] Charmaz, K., "Constructing Grounded Theory: A Practical Guide through Qualitative Analysis", Sage: London, UK, 2006

[5] Conteh, J., Gregory, E., Kearney, C. \& MorSommerfeld, A., "On Writing Educational Ethnographies", Trentham Books: Stoke on Trent, UK, 2005 
[6] Knight, S., "Risk and Adventure in Early Years Outdoor Play: lessons from Forest School", Sage: London, UK, 2011a

[7] Knight, S., "Forest School for All", Sage: London, UK, $2011 b$

[8] Knight, S., "A Pilot Study to Test the Correlation between Forest School Experiences in the Foundation Stage and Results from the Foundation Stage Profile in English Schools", Boğaziçi University Journal of Education, Boğaziçi University, Izmir, Turkey, 2011c, vol. 26 No.2

[9] Knight, S., "Forest Schools and Outdoor Play in the Early Years", Sage: London, UK, 2009

[10] Louv, R., "Last Child in the Woods" (2 $2^{\text {nd }}$ edt), London: Atalntic Books, 2010

[11] Maynard, T., "Forest Schools in Great Britain: an Initial Exploration", Contemporary Issues in Early Childhood, CIEC: online, UK, 2007a, 8 (4): 320-31,

[12] Maynard, T., 2007b, Encounters with Forest School and Foucault: a risky business? Education 3-13, Routledge: London, UK, 2007b, 35:4, 379 - 391

[13] Murray, R and O'Brien, E., "Such enthusiasm - a joy to see: an evaluation of Forest School in England", Forestry Commission, Farnham, UK, 2005

[14] Murray, R., "Forest School evaluation project: A study in Wales", New Economics Foundation: London, UK, 2003

[15] O'Brien, L., "Learning outdoors: the Forest School approach", Education 3-13, Routledge: London, UK, 2009, $37: 1,45-60$,

[16] O'Brien, L and Murray, R., "Forest School and its impact on young children: case studies in Britain", Urban Forestry and Urban Greening: Elsevier.com, 2007, 6, 249-265

[17] O’Brien, L and Murray, R, “A marvellous opportunity for children to learn: a participatory evaluation of Forest School in England and Wales", Forest Research, Farnham, UK: 2006, Downloadable from http://www.forestresearch.gov.uk/fr/INFD-5Z3JVZ

[18] Sapsed, R. \& Pereira-Stubbs, F., "Exploring a Cambridge Forest", Cambridge: Refocus Magazine: Cambridge, UK, 2009

[19] Star, S. L., "Living Grounded Theory", in Bryant, A. \& Charmaz, K., "The Sage Handbook of Grounded Theory”, London: Sage, 2007

[20] Timmermans, S. \& Tavory, I., "Advancing Ethnograhic Research through Grounded Theory Practice", in Bryant, A. \& Charmaz, K., "The Sage Handbook of Grounded Theory”, London: Sage, 2007
[21] Waite, S., Davis, B. \& Brown, K., 2006, Current Practice and Aspirations for Outdoor Learning for 2-11 year olds in Devon, Plymouth: University of Plymouth

[22] Waller, T., "The Trampoline Tree and the Swamp Monster with 18 heads: outdoor play in the Foundation Stage and Foundation Phase", Education 3-13, Routledge: London, UK, 2007, 35:4, 393 - 407

[23] Williams-Siegfredsen, J., "The Competent Child: developing children's skills and confidence using the outdoor environment: A Danish perspective", paper to British Education Research Association Early Childhood Education and Care SIG: Macclesfield, UK, 2005 